\title{
Faktor-Faktor yang Berpengaruh Dalam Penataan Pedagang Kaki Lima (PKL) pada Koridor Jalan Pasar Besar Kota Malang
}

\author{
Akhmad Raditya Maulana Fajrin dan Dian Rahmawati, ST., MT \\ Jurusan Perencanaan Wilayah dan Kota, Fakultas Teknik Sipil dan Perencanaan, Institut Teknologi \\ Sepuluh Nopember (ITS) \\ Jl. Arief Rahman Hakim, Surabaya 60111 Indonesia \\ e-mail:d_rahmawati@urplan.its.ac.id
}

\begin{abstract}
Abstrak - Kota Malang merupakan pusat orientasi bagi area Malang Raya dengan pusat Kota Malang berada pada Kecamatan Klojen. Jalan Pasar Besar merupakan bagian dari Kawasan Pasar Besar yang berfungsi sebagai kawasan bisnis atau jantung perekonomian Kota Malang, namun terdapat permasalahan yang sedang terjadi yakni keberadaan pedagang kaki lima (PKL). Keberadaan Pedagang kaki lima (PKL) menimbulkan berbagai macam persoalan perkotaan yang menyebabkan kemacetan, menurunya estetika kota dan menurunnya fungsi trotoar. Hal ini disebabkan pedagang kaki lima (PKL) yang berjualan menggunakan fasilitas umum dan pedagang tidak menata barang dagangan mereka secara rapi. Oleh karena itu, dibutuhkan kajian dalam menganilisa faktor-faktor yang berpengaruh terhadap penataan pedagang kaki lima (PKL), sebagai bahan untuk merumuskan arahan penataan pedagang kaki lima (PKL) pada Koridor Jalan Pasar Besar Kota Malang. Melalui teknik analisis Content Analyisis dapat diketahui faktor-faktor penataan pedagang kaki lima (PKL) yang berada pada Koridor Jalan Pasar Besar Kota Malang.
\end{abstract}

Hasil penelitian ini menunjukan bahwa terdapat 9 faktor yang berpengaruh dalam penataan pedagang kaki lima (PKL)

Kata Kunci-Penataan, Pedagang Kaki Lima (PKL), Pasar Besar, Kota Malang.

\section{PENDAHULUAN}

$\mathrm{P}$ EDAGANG kaki lima (PKL) merupakan salah satu bentuk kegiatan informal, dalam melakukan aktifitasnya seringkali memanfaatkan lokasi yang tidak diperuntuhkan sebagai tempat berjualan, tempat-tempat tersebut seperti badan jalan, trotoar, emperan toko dan lainlain. Pedagang kaki lima (PKL) adalah orang dengan modal relatif sedikit berusaha dibidang produksi dan penjualan barang dan jasa untuk memenuhi kebutuhan kelompok tertentu dalam masyarakat, usaha tersebut dilaksanakan ditempat yang dianggap strategis dalam suasana lingkungan yang informal [1].

Namun, keberadaan pedagang kaki lima (PKL) menimbulkan berbagai macam permasalahan perkotaan. Hal ini dikarenakan pedagang kaki lima (PKL)selalu menggunakan fasilitas umum sebagia media berjualan. Trotoar merupakan fasilitas umum yang disediakan oleh pemerintah bagi pejalan kaki, namun keberadaannya kini disalah gunakan sebagai tempat berjualan pedagang kaki lima. Para pedagang kaki lima (PKL)ini menggelar dagangan mereka secara tidak tertata, zig-zag dan seporadis sehingga menimbulkan kesan kumuh dan mengurangi estetika kota[2]. .Hal tersebut diakibatkan karena bercampur aduknya berbagai jenis dagangan yang berada pada satu lokasi dan tidak teraturnya jenis sarana berdagang para pedagang mulai dari gerobak, lapak dan sepeda serta luas sarana berdagang yang beraneka ragam, sehingga terjadi kesemerawutan[2]. Kesemerawutan ini berdampak pada para pejalan kaki yang terpaksa turun ke badan jalan untuk berjalan dikarenakan kondisi trotoar penuh sesak dengan barang dagangan ${ }^{2}$ Selain itu, kegitan pedagang kaki lima (PKL) juga menggunakan badan jalan untuk berjualan dikarenakan kondisi trotoar yang telah penuh dan sesak. Sehingga terjadi kemacetan yang terjadi akibat badan jalan di jalan Pasar Besar Malang yang merupakan kawasan padat lalu lintas menyempit, terlebih lagi banyaknya kendaraan konsumen yang berhenti untuk membeli[2]. .

Artikel ini merupakan salah satu tahapan dalam merumuskan arahan penataan pedagang kaki lima (PKL) pada Koridor Jalan Pasar Besar Kota Malang, yang dimana artikel ini akan membahas faktor-faktor yang berpengaruh dalam penataan pedagang kaki lima (PKL) pada Koridor Jalan Pasar Besar Kota Malang yang kemudian menjadi input dalam merumuskan arahan penataan pedagang kaki lima (PKL) pada Koridor Jalan Pasar Besar Kota Malang

\section{Metode Penelitian}

\section{A. Kajian pustaka}

Sebelum memasuki proses analisis dengan menggunkan teknik analisis Content Analysis, terlebih dahulu dilakukan kajian pustaka terkai penelitian ini yaitu Penataan Pedagang Kaki Lima (PKL) dengan bertujuan untuk mendapatkan variabel-varibel yang akan diteliti. Untuk lebih jelasnya dapat dilihat pada tabel dibawah ini :

Tabel 2.1

Variabel Penelitian

\begin{tabular}{cc}
\hline $\begin{array}{c}\text { No. } \\
\text { Variabel }\end{array}$ & Variabel dalam Penelitian \\
\hline 1 & Kebersihan Lokasi PKL \\
2 & Tingkat Kemacetan \\
3 & Isentif dan Disentif \\
4 & Perijinan
\end{tabular}




\begin{tabular}{cc}
\hline $\begin{array}{c}\text { No. } \\
\text { Variabel }\end{array}$ & Variabel dalam Penelitian \\
\hline 5 & Penyuluhan Tentang Sadar Hukum \\
6 & Penyuluhan Waktu Berdagang \\
7 & Interaksi Pemerintah dengan PKL \\
8 & Jaminan Perlindungan \\
9 & Pembinaan PKL \\
10 & Pengaturan Usaha \\
\hline 11 & Kerjasama antara PKL dengan Pemerintah
\end{tabular}

Sumber : Hasil Analisa, 2014

\section{B. Pendekatan penelitian}

Pendekatan yang digunakan dalam penelitian ini adalah pendekatan rasionalistik. Pendekatan rasionalistik digunakan karena penelitian ini didasarkan pada kebenaran data , serta karakteristik Pedagang Kaki Lima yang terdapat di wilayah penelitian didapatkan melalui fakta empirik.

\section{Metode Pengumpulan Data}

Pengumpulan data dan informasi dengan cara observasi langsung atau pengamatan langsung menggunakan mata tanpa ada pertolongan alat standar lain untuk keperluan tertentu. Pengamatan langsung dilakukan secara terstruktur yaitu subyek atau peneliti telah mengetahui aspek apa dari aktivitas yang diamatinya sesuai dengan masalah serta tujuan penelitian yang telah ditetapkan [4].

Wawancara semi terstruktur dapat dilakukan secara formal maupun informal, tergantung kepada lapangan dan respoden yang dihadapi. Pertanyaan wawancara berupa pernyataan penilaian terhadap faktor yang telah dirumuskan berdasarkan hasil identifikasi literatur serta pertanyaan terbuka yang dapat berkembang untuk memperoleh informasi yang lebih lengkap[5].

\section{Populasi dan Sampel}

Populasi merupakan wilayah generalisasi yang terdiri atas obyek atau subyek yang mempunyai kuantitas dan karakteristik tertentu yang ditetapkan oleh peneliti untuk dipelajari dan kemudian ditarik kesimpulannya[6].

Sampel adalah bagian dari sebuah populasi yang dianggap dapat mewakili dari populasi (sebagian atau wakil populasi yang diteliti). Untuk memperoleh sampel yang benar-benar representatif, maka teknik sampling yang digunakan haruslah sesuai.

Dalam penelitian ini sampel yang digunakan untuk mengidentifikasi faktor-faktor yang berpengaruh dalam penataan PKL menggunakan teknik purposive sampling.

\section{E. Teknik Analisis}

Dalam mencapai sasaran kedua pada penelitian ini, peneliti menggunakan teknik analisa contenct analysis. Analisis pada sasaran ini diawali dengan melakukan wawancara semi terstruktur yaitu in-depth interview kepada respoden yang telah terpilih setelah sebelumnya dilakukan teknik sampling snowball sampling. Pemilihan alat analisa content analysis pada sasaran ini dirasa tepat karena peneliti membutuhkan jawaban yang mendalam dari responden terkait faktor yang mempengaruhi. Salah satu cara untuk mendapatkan jawaban yang mendalam dari responden adalah dengan melakukan wawancara yang mendalam (in-depth interview), yang mana data hasil wawancara ini akan optimal bila dianalisis menggunakan content analysis.

Dalam proses analisis ini digunakan deductive content analysis untuk pengujian kategori konsep, model atau hipotesis. Deductive content analysis digunakan apabila struktur analisa dilakukan berdasarkan pengetahuan sebelumnya dan jika tujuan dari penelitian tersebut adalah untuk pengujian teori [7]. Untuk itu pada tahapan penelitian ini, jawaban-jawaban dari para responden akan diklasifikasikan ke dalam kategori-kategori tertentu.

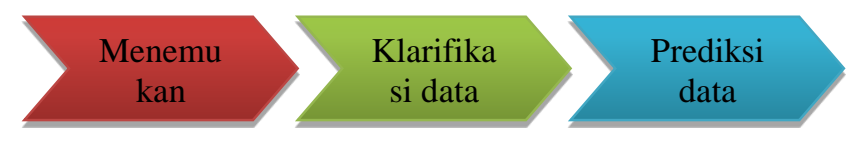

Gambar 3.1 Tahapan Content Analisis

\section{HASIL DAN DISKUSI}

\section{A. Responden Terpilih}

Responden terpilih yang digunakan dalam penelitian ini merupakan sampel yang didapatkan melalui teknik purposive sampling, dimana peneliti menggunakan Kriteria responden untuk membantu dalam proses mendapatkan responden yang memahami objek dan wilayah penelitian. Dalam hal ini, peneliti menggunakan sampel awal berupa informan kunci untuk diwawancarai. Secara spesifik metode yang digunakan untuk mengidentifikasi sampel yang terlibat adalah dengan meode pemetaan stakeholder yang berorientasi untuk mencari stakeholder kunci. Berdasarkan tahapan analisis stakeholder yang telah dilakukan, selain stakeholder kunci yang dijadikan sampel dalam penelitian, stakeholder dengan tingkat pengaruh rendah dan kepentingan tinggi juga dimasukan dalam sampel penelitian ini.

Tabel 3.1

Responden dalam Penelitian

\begin{tabular}{|c|c|c|}
\hline NO & Stakeholders & Posisi Stakeholders \\
\hline G1 & Badan Perencanaan dan & Kepala Bidang Tata Kota \\
\hline & $\begin{array}{l}\text { Pembangunan Daerah } \\
\text { (BAPPEDA) Kota Malang }\end{array}$ & \\
\hline $\mathrm{G} 2$ & Dinas Pasar Kota Malang & $\begin{array}{l}\text { Kepala Bagian Pemberdayaan } \\
\text { PKL }\end{array}$ \\
\hline G3 & $\begin{array}{l}\text { Dinas Perindustrian dan } \\
\text { Perdagangan Kota Malang }\end{array}$ & Kepala Bagian Perdagangan \\
\hline G4 & $\begin{array}{l}\text { Satuan Polisi Pamong Praja } \\
\text { (Satpol PP) Kota Malang }\end{array}$ & $\begin{array}{lr}\text { Kepala Seksi } & \text { Keamanan dan } \\
\text { ketertiban } & \text { masyarakat } \\
\text { (Trantibmas) } & \end{array}$ \\
\hline $\mathrm{S} 1$ & $\begin{array}{l}\text { Paguyuban Pedagang Kaki } \\
\text { Lima (PKL) Pasar Besar Kota } \\
\text { Malang }\end{array}$ & $\begin{array}{l}\text { Ketua Paguyuban PKL Pasar } \\
\text { Besar }\end{array}$ \\
\hline $\mathrm{S} 2$ & $\begin{array}{l}\text { Akademisi PWK ITN Kota } \\
\text { Malang }\end{array}$ & $\begin{array}{l}\text { Dosen dengan keahlian tata kota } \\
\text { dan manajamen perkotaan }\end{array}$ \\
\hline S3 & Tokoh Masyarakat & Ketua RT \\
\hline
\end{tabular}

Sumber : Hasil Analisa, 2014 


\section{B. Menemukan Kode}

Menemukan kode didasarkan dari transkrip wawancara yang telah dilakukan oleh stakeholders dengan terelbih dahulu melalui in-dept interview. Menemukan kode ini bertujuan untuk mengethaui variabel penataan pedagang kaki lima (PKL) apakah berindikasi berpengaruh tau tidak pada suatu transkrip wawancara yang telah dilakukan. Berikut dibawah ini merupakan contoh penemuan kode dalam transkrip wawancara.

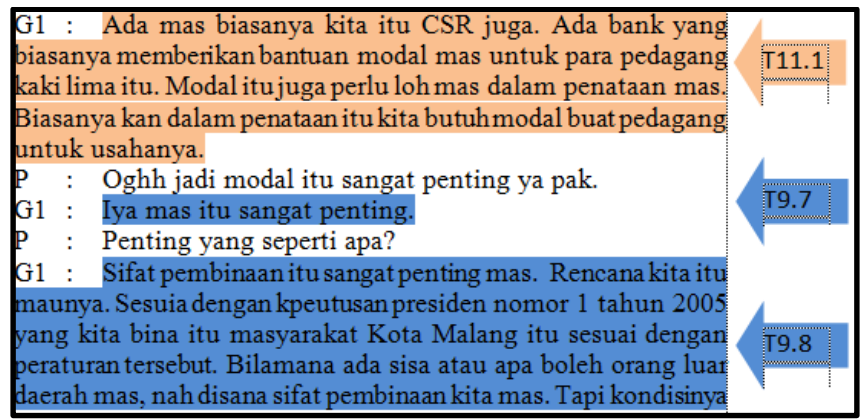

Gambar 3. Kutipan temuan kode pada stakeholder 1 (G1)

Transkrip 1)

Berdasarkan kutipan diatas dapat diketahui bahwa terdapat unit analisa yang diutarakan oleh stakeholder 1 (G1), yang mengindikasikan makna bahwa variabel kerjasama antara pemerintah dengan pedagang kaki lima (PKL) (T.11.1) merupakan variabel yang berpengaruh yang dipengaruhi oleh modal untuk berdagang para pedagang kaki lima (PKL)

tersebut menyimpulkan bahwa stakeholder 1 menganggap variabel ini berpengaruh. Proses pengodean dimana dititikberatkan terhadap makna unit analisa berlaku untuk menemukan indikasi pengaruh suatu variabel pada stakeholder lainnya. Selain makna dari unit analisa untuk mengindikasikan pengaruh, jumlah unit analisa yang berulang dengan makna yang sama mendukung penyimpulan indikasi dan signifikasi suatu pengaruh variabel penataaan .

Berdasarkan keseluruhan hasil pengodean tersebut, variabel Penataan PKL terbagi menjadi 2 kelompok, yaitu Variabel Penataan yang berpengaruh dan variabel Penataan yang tidak berpengaruh.Hasil pengodean tersebut disederhanakan dalam bentuk tabel di bawah ini.

Tabel 3.2

Frekuensi Konfirmasi Stakeholders setiap variable Penataan

\begin{tabular}{lcc}
\hline \multirow{2}{*}{ Variabel Penataan } & \multicolumn{2}{c}{ Jumlah Stakeholders } \\
\cline { 2 - 3 } & $\begin{array}{c}\text { Mengonformasi } \\
\text { berpengaruh }\end{array}$ & $\begin{array}{c}\text { Mengonfirmasi tidak } \\
\text { berpengaruh }\end{array}$ \\
\hline Kebersihan Lokasi & 27 & 2 \\
PKL & 25 & - \\
Tingkat Kemacetan & 25 & 2 \\
Isentif Dan Disentif & 25 & - \\
Perijinan & 17 & - \\
Penyuluhan Tentang & & - \\
Sadar Hukum & 23 & - \\
Penyuluhan Waktu & & - \\
Berdagang & 23 & \\
Interaksi Pemerintah & & \\
dengan PKL & 27 & \\
Jaminan Perlindungan & &
\end{tabular}

Pembinaan PKL

Pengaturan Usaha

23

3

Kerjasama antara

PKL dengan

Pemerintah

Sumber : Hasil Analisis, 2015

\section{Eksplorasi}

Dalam tahapan ini peneliti mengeksporasi apakah terdapat variabel yang berpengaruh diluar dari variabel yang telah ditemukan oleh penliti.

Berdasarkan hasil wawancara terdapat variabel penataan temuan baru yang diungkapkan oleh beberapa stakeholders untuk lebih jelasnya dapat dilihat pada tabel dibawah ini :

Tabel 3.3

Variabel Temuan Baru

\begin{tabular}{lcc}
\hline \multirow{2}{*}{ Variabel Penataan } & \multicolumn{2}{c}{ Jumlah Stakeholders } \\
\cline { 2 - 3 } & $\begin{array}{c}\text { Mengonformasi } \\
\text { berpengaruh }\end{array}$ & $\begin{array}{c}\text { Mengonfirmasi tidak } \\
\text { berpengaruh }\end{array}$ \\
\hline Modal Usaha & 14 & - \\
Fasilitas Penunjang & 19 & - \\
\hline
\end{tabular}

Sumber : Hasil Analisis, 2015

Hasil temuan baru ini akan diolah bersama dengan variabel penataan pedagang kaki lima yang berpengaruh dalam proses selanjiutnya, yaitu unutuk menentukan faktor-faktor yang berpengaruh.

\section{Prediksi data (Abstraksi Hasil)}

Dalam tahapan ini hasil variabel yang berpengaruh akan ditransformasikan kedalam bentuk faktor-faktor penataan pedagang kaki lima (PKL) yang berada pada Koridor Jalan Pasar Besar Kota Malang. Pada tahapan ini variabel akan dibandingkan dengan kondisi eksisting dan teori yang berkaitan sehingga didapatkan faktor. Untuk lebih jelasnya dapat dilihat pada contoh tabel dibawah ini :

Tabel 3.4

\begin{tabular}{|c|c|c|c|}
\hline \multicolumn{4}{|c|}{ Penjabaran Faktor-Faktor Yang Berpengaruh } \\
\hline Variabel & $\begin{array}{l}\text { Kondisi } \\
\text { eksisiting }\end{array}$ & $\begin{array}{l}\text { Teori yang } \\
\text { berkaitan }\end{array}$ & Faktor \\
\hline $\begin{array}{l}\text { Kebersih } \\
\text { an Lokasi } \\
\text { PKL }\end{array}$ & $\begin{array}{l}\text { Kebersihan } \\
\text { PKL masih } \\
\text { dirasa } \\
\text { kurang hal } \\
\text { ini } \\
\text { disebabkan } \\
\text { kurangny } \\
\text { kesadaran } \\
\text { PKL } \\
\text { dengan } \\
\text { ditandainya } \\
\text { banyaknya } \\
\text { sampah } \\
\text { yang } \\
\text { ditimbulkan } \\
\text { oleh PKL }\end{array}$ & $\begin{array}{l}\text { Hambatan } \\
\text { utama penataan } \\
\text { kebersihan } \\
\text { adalah } \\
\text { kurangnya } \\
\text { kesadaran } \\
\text { kolektif para } \\
\text { pedagang akan } \\
\text { kebersihan, } \\
\text { mereka } \\
\text { cenderung } \\
\text { mengabaikan } \\
\text { kebersihan dan } \\
\text { menyerahkan } \\
\text { sepenuhnya } \\
\text { kepada petugas } \\
\text { kebersihan. } \\
\text { Disamping itu } \\
\text { 46ector drainase } \\
\text { lingkungan } \\
\text { yang buruk, } \\
\text { saluran air yang } \\
\text { kurang juga } \\
\text { memadai ji } \\
\text { mempengaruhi } \\
\text { kualitas } \\
\text { lingkungan di }\end{array}$ & $\begin{array}{l}\text { Kesadaran kolektif para } \\
\text { pedagang } \\
\text { kebersihan, } \\
\text { cenderung mengabaikan } \\
\text { kebersihan } \\
\text { menyerahkan } \\
\text { sepenuhnya kepada } \\
\text { petugas kebersihan. Pada } \\
\text { kondisi eksisiting kondisi } \\
\text { kebersihan PKL masih } \\
\text { sangat kurang dengan } \\
\text { ditandai banykanya } \\
\text { sampah padaa sudut- } \\
\text { sudut jalan. Sehingga } \\
\text { salah satu faktor yang } \\
\text { berpengaruh dalam } \\
\text { penataan pedagang kaki } \\
\text { lima adalah rendahnya } \\
\text { kebersihan pada lokasi } \\
\text { berdagang PKL. }\end{array}$ \\
\hline
\end{tabular}




\begin{aligned} & \hline sekitar lokasi \\ & PKL. \\ & Sumber : Hasil Analisis, 2015\end{aligned}

Setalah didapatkan faktor-faktor yang berpengaruh dalam penataan pedagang kaki lima (PKL) berdasarkan variabel dengan meninjau kondisi eksisting dan teori yang berkaitan didapatkan 13 faktor- faktor yang berpengaruh. Namun, faktorfaktor tersebut tereduksi dan terjadi penggabungan antara beberapa faktor-faktor. Hal ini dikarenakan karena kesamaan maksud dan tujuan sehingga terjadi penggabungan. Untuk lebih jelasnya faktor-faktor yang berpengaruh dalam penataan pedagang kaki lima (PKL) pada Koridor Jalan Pasar Besar Kota Malang yang digunkan dalam penelitian ini dapat dilihat pada tabel dibawah ini:

\section{Tabel 3.5}

Faktor-faktor yang berpengaruh dalam penataan

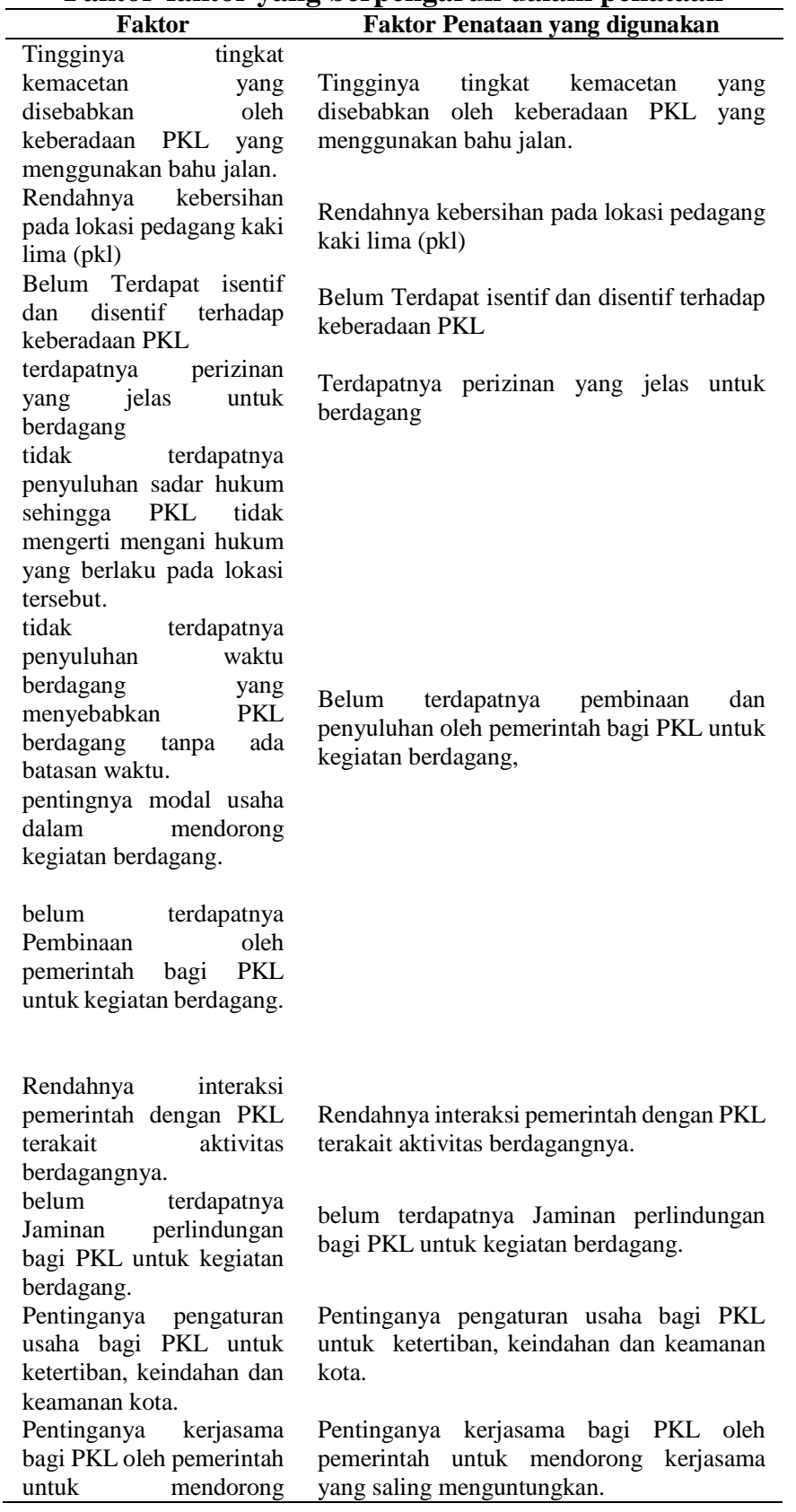

kerjasama yang saling

menguntungkan.

Sumber : Hasil Analisis, 2015

Selain itu, faktor-faktor penataan tersebut akan dijabarkan berdasarkan alasan akan pengaruhnya serta komposisi konfirmasi pengaruhnya oleh stakeholders.

Maka berikut di bawah ini lebih jelasnya mengenai faktor faktor penataan pedagang kaki lima (PKL) yang berpengaruh pada Koridor Jalan Pasar Besar Kota Malang.

1. Faktor Tingginya tingkat kemacetan yang disebabkan oleh keberadaan PKL yang menggunakan bahu jalan.

Berdasarkan kombinasi hasil, diketahui seluruh stakeholder menyepakati bahwa faktor tingginya tingkat kemacetan berpengaruh dalam penataan pedagang kaki lima (PKL) yang berada di wilayah penelitian, dengan alasan bahwa tingkat kemacetan merupakan salah satu bentuk kegiatan yang diakibatkan oleh PKL yang banyak berdagang di bahu dan trotoar jalan yang semestinya tidak diperbolehkan karena dapat mengurangi lebar ruas jalan dan banyak kendaraan pembeli yang berhenti tepat di depan PKL untuk berbelanja sehingga menimbukan kemacetan. Dari total keseluruhan pernyataan yang terulang sebanyak 25 kali dan seluruhnya menyatakan berpengaruh maka dapat disimpulkan bahwasannya faktor ini BERPENGARUH

\section{Faktor Rendahnya kebersihan pada lokasi pedagang kaki lima $(P K L)$}

Berdasarkan kombinasi hasil, diketahui seluruh stakeholder menyepakati bahwa Faktor Tingginya tingkat kemacetan yang disebabkan oleh keberadaan PKL yang menggunakan bahu jalan berpengaruh dalam penataan pedagang kaki lima yang berada di wilayah penelitian, dengan alas an bahwa kebersihan merupakan salah satu bentuk keindahan kota terlebih lagi keberadaan PKL saat ini sangat memprihatinkan. Dengan adanya kebersihan ini pembeli dan pedagang sama-sama di untungkan. Tidak ada namanya sampah yang berserakan, selain itu kebersihan ini juga mementingkan makanan sehat dan layak jual. Dari total keseluruhan pernyataan yang terulang sebanyak 27 kali dan seluruhnya menyatakan berpengaruh maka dapat disimpulkan bahwasannya faktor ini BERPENGARUH

\section{Faktor Belum Terdapat isentif dan disentif terhadap keberadaan PKL}

Berdasarkan kombinasi hasil, diketahui seluruh stakeholder menyepakati bahwa faktor isentif dan disisentif berpengaruh dalam penataan pedagang kaki lima yang berada di wilayah penelitian, dengan alasan bahwa dengan adanya isentif dan didisentif ini kita dapat menekan jumlah pelanggaran yang dilakukan oleh pedagang dan juga dapat mengatur keberdaan pedagang dengan pemeberian peraturan dan sanksi dengan jelas. Dari total keseluruhan pernyataan yang terulang sebanyak 25 kali dan seluruhnya menyatakan berpengaruh maka dapat disimpulkan bahwasannya faktor ini SANGAT BERPENGARUH

4. Faktor Terdapatnya perizinan yang jelas untuk berdagang 
Berdasarkan kombinasi hasil , diketahui seluruh stakeholder menyepakati bahwa faktor Perijinan berpengaruh dalam penataan pedagang kaki lima yang berada di wilayah penelitian, dengan alasan perijinan adalah dasar hukum keberadaan PKL atas lokasi yang mereka tempati, sehingga keberadaan PKL ini dapat pertanggung jawabkan. Dari total keseluruhan pernyataan yang terulang sebanyak 25 kali dan seluruhnya menyatakan berpengaruh maka dapat disimpulkan bahwasannya faktor ini BERPENGARUH

5. Faktor Belum terdapatnya pembinaan dan penyuluhan oleh pemerintah bagi pedagang kaki lima (PKL) untuk kegiatan berdagang.

Berdasarkan kombinasi hasil, diketahui seluruh stakeholder menyepakati bahwa faktor Peryuluhan tentang waktu berdagang, sadar hukum serta pembinaan berpengaruh dalam penataan pedagang kaki lima yang berada di wilayah penelitian, dengan alasan PKL sangat memerlukan penyuluhan waktu berdagang. Dari total keseluruhan pernyataan yang terulang sebanyak 63 kali dan seluruhnya menyatakan berpengaruh maka dapat disimpulkan bahwasannya faktor ini BERPENGARUH

6. Faktor Rendahnya interaksi pemerintah dengan
Pedagang Kaki Lima (PKL) terkait aktivitas
berdagangnya.

Berdasarkan kombinasi hasil , diketahui seluruh stakeholder menyepakati bahwa faktor interaksi dengan pemerintah berpengaruh dalam penataan pedagang kaki lima yang berada di wilayah penelitian, dengan alasan interaksi pemerintah dengan PKL sangat penting dalam membuta kesepakatan.. Dari total keseluruhan pernyataan yang terulang sebanyak 23 kali dan seluruhnya menyatakan berpengaruh maka dapat disimpulkan bahwasannya faktor ini BERPENGARUH

\section{Faktor Belum terdapatnya jaminam perlindungan bagi pedagang kai lima (PKL) untuk kegiatan berdagang.}

Berdasarkan kombinasi hasil, diketahui seluruh stakeholder menyepakati bahwa faktor Jaminan perlindungan berpengaruh dalam penataan pedagang kaki lima yang berada di wilayah penelitian, dengan alasan jaminan perlindungan adalah dasar hukum keberadaan PKL atas lokasi yang mereka tempati, sehingga keberadaan PKL ini dapat pertanggung jawabkan. Dari total keseluruhan pernyataan yang terulang sebanyak 27 kali dan seluruhnya menyatakan berpengaruh maka dapat disimpulkan bahwasannya faktor ini BERPENGARUH

8. Faktor Pentingnya pengaturan usaha bagi pedagang kaki lima (PKL) untuk ketertiban, keindahan dan keamanan kota

Berdasarkan kombinasi hasil, diketahui seluruh stakeholder menyepakati bahwa faktor Pengaturan usaha berpengaruh dalam penataan pedagang kaki lima yang berada di wilayah penelitian, dengan alasan pengaturan usaha, diperlukan unutk menciptakan kondisi yang tepat, ketika banyak PKL yang tidak dapat diatur. Dari total keseluruhan pernyataan yang terulang sebanyak 27 kali dan seluruhnya menyatakan berpengaruh maka dapat disimpulkan bahwasannya faktor ini BERPENGARUH

9. Faktor Pentingnya kerjasama bagi pedagang kaki lima $(P K L)$ oleh pemerintah untuk mendorong kerjasama yang saling menguntungkan

Berdasarkan kombinasi hasil, diketahui seluruh stakeholder menyepakati bahwa faktor kerjasama berpengaruh dalam penataan pedagang kaki lima yang berada di wilayah penelitian, dengan alasan kerja sama merupakan salah satu cara agar mencapai ksepakatan antara PKL dengan Pemerintah. Dari total keseluruhan pernyataan yang terulang sebanyak 31 kali dan seluruhnya menyatakan berpengaruh maka dapat disimpulkan bahwasannya faktor ini BERPENGARUH

\section{KESIMPULAN}

Berdasarkan hasil analisa dan pembahasan yang telah dilakukan pada penelitian ini, maka dapat disimpulkan bahwa:

1) Terdapat 2 temuan baru variabel penataan pedagang kaki lima (PKL) Pada Koridor Jalan Pasar Besar Kota Malang yakni Variabel Modal Usaha dan Variabel Fasilitas Penunjang.

2).Terdapat 13 Variabel penataan pedagang kaki lima (PKL) yang dinyatakan berpengaruh yang sealnjutnya untuk menjadi masukan untuk dijadikan faktor-faktor.

4) Variabel penataan terhadap PKL yang paling berpengaruh melihat dari jumlah konfirmasi pengaruh oleh stakeholder dan iterasi unit analisa adalah variabel kondisi drainase dan jarak dari sungai dimana seluruh stakeholders sepakat menyatakan berpengaruh dengan pengulangan unit analisa dengan maksud yang sama paling banyak, dimana masing-masing 27 kali untuk variabel Kebersihan lokasi PKL dan Jaminan terhadap PKL dalam seluruh transkrip wawancara.

5) Penataan pedagang kaki lima (PKL) pada Koridor Jalan Pasar besar Kota Malang dipengaruhi 9 faktor Penataan,antara lain: Faktor Tingginya tingkat kemacetan yang disebabkan oleh keberadaan PKL yang menggunakan bahu jalan, Faktor Rendahnya kebersihan pada lokasi pedagang kaki lima (PKL), Faktor Belum Terdapat isentif dan disentif terhadap keberadaan PKL, Faktor Terdapatnya perizinan yang jelas untuk berdagang, Faktor Belum terdapatnya pembinaan dan penyuluhan oleh pemerintah bagi pedagang kaki lima (PKL) untuk kegiatan berdagang, Faktor Rendahnya interaksi pemerintah dengan Pedagang Kaki Lima (PKL) terkait aktivitas berdagangnya, Faktor Belum terdapatnya jaminam perlindungan bagi pedagang kai lima (PKL) untuk kegiatan berdagang, Faktor Pentingnya pengaturan usaha bagi pedagang kaki lima (PKL) untuk ketertiban, keindahan dan keamanan kota, Faktor Pentingnya kerjasama bagi pedagang kaki lima (PKL) oleh pemerintah untuk mendorong kerjasama yang saling menguntungkan

4) Dalam penelitian ini hanya melihat persepsi stakeholders terpilih dan teori yang relevan, sehingga dibutuhkan kajian empiris berbasis observasi untuk lebih meningkatkan validitas dari hasil penelitian yang dihasilkan dari content analysis. 


\section{UCAPAN TERIMA KASIH}

"Penulis A.R.M.F mengucapkan terima kasih kepada Dian Rahmawati, ST., MT yang telah membimbing peneliti hingga mampu menyelesaikan penelitian ini hingga akhir. Terimakasih pula kepada Dinas, Praktisi, Akedemisi dan Paguyuban PKL Pasar Besar yang telah membantu peneliti dalam menyelesaikan penelitian ini.

\section{DAFTAR PUSTAKA}

[1] Haryono, Tulus, 1989. Faktor-Faktor yang Mempengaruhi Keberhasilan Usaha Pedagang Kaki Lima : Studi Kasus di Kodya Surakarta (tesis yang tidak dipublikasikan, Fakultas Pasca Sarjana, Universitas Gadjah Mada).

[2] Maharani, Malang-post.com. 2014. Pedagang kaki lima penyebab kemacetan di jalan pasar besar Dikases tanggal 8 Oktober 2014 pukul 18.30 BBWI

[3] Alisjahbana. 2003. Marginalisasi Sektor Informal Perkotaan. Surabaya : ITS Press.

[4] Hidayat, 1978. "Peranan Sektor Informal dalam Perekonomian Indonesia", Ekonomi Keuangan Indonesia, Vol. XXVI, No. 4, Desember 1978, hal

[5] De Soto, H. 1991. Masih Ada Jalan Lain: Revolusi Tersembunyi di Negara Dunia Ketiga. Jakarta: Yayasan Obor Indonesia..

[6] Arikunto, Suharsimi. 2006. Prosedur Penelitian, Suatu Pendekatan Praktik. Jakarta: Penerbit PT Rineka Cipta.

[7] Metodologi Penelitian Kualitatif. Yogyakarta: Penerbit Rake Sarasin. 